\title{
Map of Indonesia
}

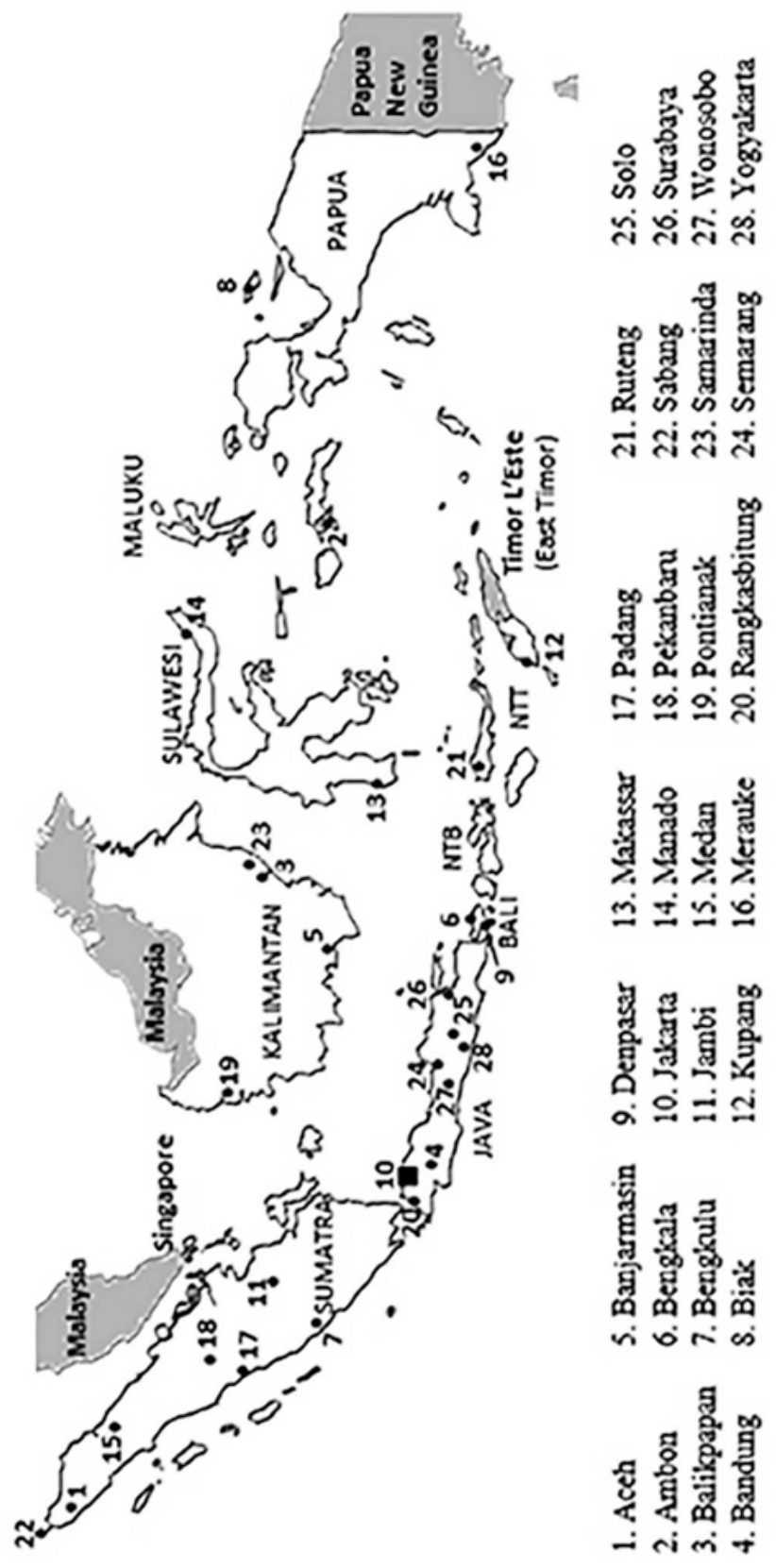


